\title{
Retinol, alpha-tocopherol and fatty acid content in Bulgarian Black Sea fish species
}

\author{
By M. Stancheva, B. Galunska, A.D. Dobreva* and A. Merdzhanova
}

\author{
Department of Chemistry, Faculty of Pharmacy, Medical University of Varna, Bulgaria \\ ${ }^{\star}$ Corresponding author: didobreva@ gmail.com
}

\section{RESUMEN}

Retinol, alfa-tocoferol y contenido en ácidos grasos de especies de peces búlgaros del Mar Negro.

El objeto de la investigación presentada es definir y comparar los lípidos totales, el perfil de ácidos grasos y el contenido de retinol y alfa-tocoferol en el tejido comestible de cuatro especies de peces con importancia comercial del Mar Negro búlgaro - espadín (Sprattus Sprattus), gobio de boca negra (Neogobius Melanostomus), chicharro (Trachurus Trachurus) y sábalo del Mar Negro (Caspialosa Pontica). Dos vitaminas liposolubles son analizadas simultáneamente mediante cromatografía líquida de alta eficacia (HPLC). El contenido mayor de retinol se encuentra en el espadín $(142.3 \pm 4.4 \mu \mathrm{g} / 100 \mathrm{~g})$, y de alfa-tocoferol en el chicharro $(1112.7 \pm 39.2 \mu \mathrm{g} / 100 \mathrm{~g})$. El contenido de ácidos grasos ha sido analizado mediante cromatografía gaseosa/espectrometría de masas (GC/MS). El contenido de ácidos grasos (AG) omega-3 (n3) es considerablemente más alto que el contenido de ácidos grasos (AG) omega- 6 en todas las especies analizadas. La proporción n6/n3 está en el intervalo recomendado $(0.2-1.5)$ para el espadín, el gobio de boca negra y el sábalo del Mar Negro. Los niveles relativamente altos de retinol, alfa-tocoferol, relaciones de ácidos grasos, n6/n3 AG y PUFA/SFA muestran que todas estas especies de peces poseen buenas propiedades nutricionales.

PALABRAS CLAVE: Alosa pontica - Mar Negro - Neogobiusrattan - Sprattus sprattus - Trahurus medditeraneus ponticus.

\section{SUMMARY}

Retinol, alpha-tocopherol and fatty acid content in Bulgarian Black Sea fish species.

The aim of the present study was to measure and evaluate the total lipids, fatty acid profile, retinol content and alpha-tocopherol content in the edible tissue of four commercially important fish species from the Bulgarian Black sea: Sprat (Sprattus sprattus), Round Goby (Neogobius rattan), Black Sea Horse Mackerel (Trahurus medditeraneus ponticus) and Shad (Alosa pontica). Fat soluble vitamins were analyzed simultaneously using an HPLC system. The highest content of retinol was established in the Sprat $(142.3 \pm 4.4 \mu \mathrm{g} / 100 \mathrm{~g})$ and the highest content of alphatocopherol was found in the Black Sea Horse Mackerel $(1112.7 \pm 39.2 \mu \mathrm{g} / 100 \mathrm{~g})$. The fatty acid (FA) composition was analyzed by GC/MS. The content of omega 3 (n3) FAs was significantly higher $(p<0.001)$ than the content of omega 6 (n6) FAs in each of the analyzed fish samples. The n6/n3 FA ratio was within the recommended range $(0.20-1.50)$ for Sprat, Round Goby and Shad. Relatively high levels of retinol and alpha-tocopherol, FA composition, n3/n6 FA and PUFA/SFA ratios indicate that these fish species have good nutritional quality.

KEY-WORDS: Alosa pontica - Black sea - Neogobius rattan - Sprattus sprattus - Trahurus medditeraneus ponticus.

\section{INTRODUCTION}

Fish is an important component of a healthy diet, providing a number of substantial nutrients that are essential for achieving a balanced nutrition for children, adults and the elderly. Fish tissue is a good source of fats, proteins, vitamins and minerals. Lipids of marine fish species are rich sources of fat soluble vitamins and both saturated and unsaturated fatty acids (Tocher, 2003). The fat soluble vitamins are essential nutrients related to a diversity of biologically important processes in the human body. Retinol takes place in photo reception, regulates gene expression and cell proliferation, bone growth and reproduction. The biologically active isomer of vitamin $\mathrm{E}$ - alpha-tocopherol acts as an antioxidant protecting membrane structures and lipo proteins from oxidation (Anderson J. and Young L., 2008). Polyunsaturated fatty acids (PUFA) derived from fish lipids are key constituents of membrane phospholipids, precursors for the biosynthesis of biologically important hormone-like substances such as eicosanoids. Seawater fish fatty acid (FA) composition is unique and is characterized by low levels of n6 FA (linoleic acid LA, C18:2 n6) and high levels of n3 PUFA (eicosapentaenoic acid, EPA C20:5n3; docosahexaenoic acid, DHA C22:6n3) (Tanakol et al., 1999; Tocher, 2003; Abas et al., 2009).

On the recommendations of the World Health Organization (WHO) and the Food and Agricultural Organization (FAO) it is advisable to consume annually at least $15-20 \mathrm{~kg}$ of fish per capita (FAO/ WHO, 1994). In Bulgaria, the Black Sea is the main resource for fishing. It is an unique semi-closed basin with slow water circulation, relatively low salinity (e.g. compared with the Mediterranean) and high eutrophication, inhabited by about 140 fish species of which only 15 are commercially important. The catches in the Black Sea account for approximately $89.7 \%$ of the total fish production in 
Bulgaria. Traditionally consumed in Bulgaria are four Black Sea fish species: the Sprat, the Round Goby, the Black Sea Horse Mackerel and the Shad. One of them, the Sprat, comprises the highest percentage of the total fish catch in Bulgaria (40.86\%) (National Strategic Plan, 2007).

Surprisingly, the information in the literature regarding the $F A$ composition and fat soluble vitamin contents of local traditionally consumed marine fish species is very scarce. Most of the studies are focused mainly on the evaluation of the fat soluble vitamin contents of fish inhabiting other than the Black Sea Basin area (Dias et al., 2003; Kuhnlein et al., 2006).

For this reason, we aimed to analyze and to evaluate the retinol and alpha-tocopherol content and FA composition of four traditionally consumed sea fish from the Bulgarian Black Sea: Sprat (Sprattus sprattus), Round Goby (Neogobius rattan), Black Sea Horse Mackerel (Trahurus medditeraneus ponticus) and Shad (Alosapontica).

\section{MATERIALS AND METHODS}

\subsection{Fish species}

Sprat (Sprattus sprattus), Round Goby (Neogobius rattan), Black Sea Horse Mackerel (Trahurus medditeraneus ponticus) and Shad (Alosa pontica) were used for the analyses of fat soluble vitamin contents and FA composition. All of them were caught from the Bulgarian Black Sea and purchased from the Varna fish market during the spring of 2009. Biological and biometrical characteristics of the fish species are given in Table 1.

All fish were immediately frozen at $-20^{\circ} \mathrm{C}$ and stored in a fridge for 48 hours. Prior to analysis, the fish were defrosted, filleted and used as raw material for the preparation of a random sample of fish tissue. The edible fish tissue was filleted with the skin left on and homogenized using a kitchen homogenizer for $3 \mathrm{~min}$.

\subsection{Lipid extraction}

Aliquots of freshly prepared homogenate $(5.00 \mathrm{~g})$ were extracted according to the method of Bligh and Dyer (Bligh and Dyer, 1959) using chloroform/ methanol/water in a ratio 2:2:1. After phase separation, the chloroform extracts were evaporated to dry residues and were quantified by weight. The total lipid content was determined gravimetrically for each fish sample. The results were expressed as $\mathrm{g}$ per $100 \mathrm{~g}$ raw tissue $\left(\mathrm{g} .100 \mathrm{~g}^{-1}\right.$ r.t.).

\subsection{Vitamin analysis}

The pre-analytical sample preparation was done according to the method of Sánchez-Machado et al. (Lopez-Cervantes et al., 2006) with slight modifications: $0.50 \mathrm{~g}$ of the homogenized fish tissue were weighed into a glass vial with a screw cap. For the saponification step $2 \mathrm{~mL}$ of $1 \%$ methanolic L-ascorbic acid and $5 \mathrm{~mL}$ of $0.5 \mathrm{M}$ methanolic potassium hydroxide were added and the vials were incubated in a water bath at $80^{\circ} \mathrm{C}$ for $20 \mathrm{~min}$. Retinol and alpha-tocopherol were extracted from the methanolic solution with n-hexane. After phase separation, the hexane layer was gently evaporated under nitrogen. The dry residue was dissolved in $400 \mu \mathrm{L}$ of mobile phase and $20 \mu \mathrm{L}$ were injected into the HPLC system.

An HPLC system (Thermo Scientific Spectra SYSTEM, USA) equipped with a UV2000 detector and analytical column ODS2 Hypersil ${ }^{\mathrm{TM}} 250 \times 4$, $6 \mathrm{~mm}, 5 \mu \mathrm{m}$ (Thermo Scientific, USA) was used. The mobile phase was $100 \%$ methanol at a flow rate of $0.9 \mathrm{~mL} / \mathrm{min}$. The qualitative analysis was performed by comparing the retention times of standard solutions of all-trans-retinol and alphatocopherol, absorbing at $\lambda_{\max }=325 \mathrm{~nm}$ and $\lambda_{\max }=295 \mathrm{~nm}$ respectively. All-trans-retinol and alphatocopherol standards as well as other HPLC-grade reagents were purchased from Sigma-Aldrich ${ }^{\mathrm{TM}}$, USA. The quantification was done by the method of external calibration comparing the sample peak areas with the corresponding standard peak areas. Standard curves for all trans-retinol and alphatocopherol were constructed in triplicate using six different concentrations of standard solutions. The reproducibility, estimated by the coefficients of variation of ten parallel samples was calculated as 3.76-7.79\% for all-trans retinol and $4.07-7.06 \%$ for alpha-tocopherol. The average analytical recoveries of retinol and alpha-tocopherol of the spiked fish samples were $91 \%$ and $96 \%$, respectively. The fat

Table 1

Biometrical and biological characteristics of the analyzed fishes (mean \pm SD)

\begin{tabular}{|c|c|c|c|c|c|c|}
\hline \multirow{2}{*}{ Fish species } & \multirow{2}{*}{$\begin{array}{l}\text { Mean total } \\
\text { weight [g] }\end{array}$} & \multirow{2}{*}{$\begin{array}{l}\text { Mean total } \\
\text { length }[\mathrm{cm}]\end{array}$} & \multicolumn{2}{|c|}{ Habitat } & \multicolumn{2}{|c|}{ Food habits } \\
\hline & & & Pelagic & Demersal & Planktivorous & Carnivorous \\
\hline Sprat $(n=33)$ & $10.0 \pm 0.3$ & $12.0 \pm 0.2$ & + & - & + & - \\
\hline Round goby $(\mathrm{n}=12$ ) & $45.0 \pm 1.0$ & $16.0 \pm 1.1$ & - & + & - & + \\
\hline $\begin{array}{l}\text { Black sea horse } \\
\text { mackerel }(n=21)\end{array}$ & $19.5 \pm 1.5$ & $14.0 \pm 1.1$ & + & - & - & + \\
\hline Shad $(n=6)$ & $325.0 \pm 5.0$ & $25.0 \pm 2.1$ & + & - & - & + \\
\hline
\end{tabular}


soluble vitamin content was expressed as $\mu \mathrm{g} \cdot 100 \mathrm{~g}^{-1}$ raw tissue $\left(\mu \mathrm{g} .100 \mathrm{~g}^{-1}\right.$ r.t.).

\subsection{Fatty Acid analysis}

The dry residues used for the determination of total lipids were dissolved in $2 \mathrm{~mL} n$-hexane and then methylated by base-catalyzed transmethylation using $1 \mathrm{~mL} 2 \mathrm{M}$ methanolic potassium hydroxide and $\mathrm{n}$-hexane. The methylation of the free FA fraction was evaluated by the method of internal standard using $1 \mathrm{mg} / \mathrm{mL}$ C19:0 methanolic solution. After centrifugation (3500 rps), the hexane layer was separated and analyzed by GC-MS (BDS EN ISO 5509:2000).

Gas chromatography analyses were performed by a model FOCUS Gas Chromatograph with an auto sampler A2000, equipped with a Polaris Q MS detector (Thermo Scientific, USA). The capillary column used was a TR-5 MS (Thermo Scientific, USA) universal column $30 \mathrm{~m}$ length and $0.25 \mathrm{~mm}$ i.d. Helium was used as a carrier gas at a flow rate $1 \mathrm{~mL} / \mathrm{min}$ (BDS EN ISO 5508:2000). Peak identification was done by two parameters: retention time (RT) based on fatty acid methyl esters (FAME) mix standard and mass spectra (ratio $\mathrm{m} / \mathrm{z}$ ), compared to an internal Data Base (Thermo Sciences Mass Library, USA). Fas and methyl esters were mixed and a standard solution (F.A.M.E. Mix C4-C24, Supelco, Sigma-Aldrich ${ }^{\mathrm{TM}}$, USA) containing all FAs of interest was used for their identification. FAMEs were quantified by the method of external standard. The FA content was expressed as percentage of total FAs content.

\subsection{Statistical analysis}

A Statistical analysis was done using GrapgPad Prizm 5, USA software. Column statistics were used for calculation of the means, standard deviations, and the coefficients of variation. The Student's t-test was used to evaluate the differences among the means. Statistical significance was indicated at $p<0.05$.

\section{RESULTS AND DISCUSSION}

\subsection{Total lipid content}

The lowest total lipid content was found in the Round Goby $\left(1.60 \pm 0.05 \mathrm{~g} .100 \mathrm{~g}^{-1}\right.$ r.t.) followed by the Sprat $\left(2.5 \pm 0.09 \mathrm{~g} .100 \mathrm{~g}^{-1} \mathrm{r}\right.$.t. $)$ and the Black Sea Horse Mackerel $\left(4.15 \pm 0.15 \mathrm{~g} .100 \mathrm{~g}^{-1}\right.$ r.t. $)$, whereas the Shad $\left(13.15 \pm 0.25 \mathrm{~g} .100 \mathrm{~g}^{-1}\right.$ r.t.) was the fish with the highest content of total lipids (Fig. 1).

\subsection{Retinol and alpha-tocopherol content}

The content of retinol and alpha-tocopherol varied in wide ranges among fish species (Table 2). The highest retinol concentration was measured

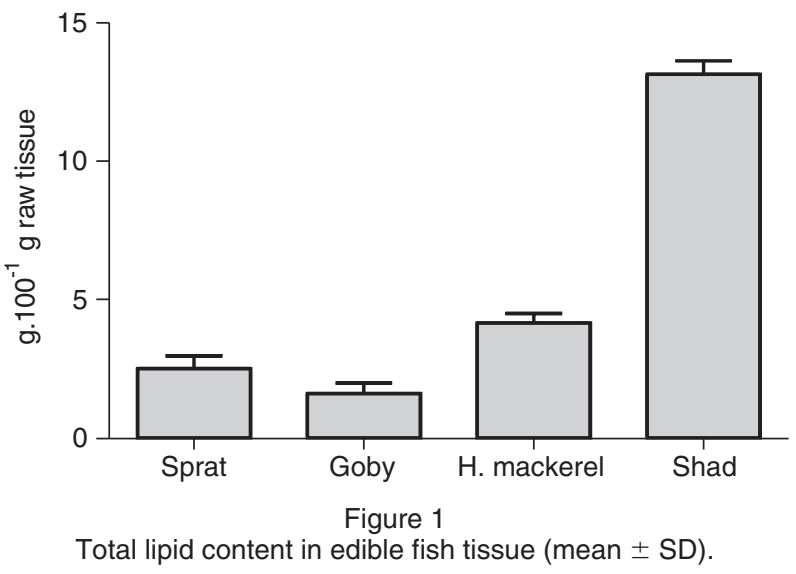

in the Sprat, while the Black Sea Horse Mackerel was the richest source of alpha-tocopherol among the analyzed fish species. Since retinol and alphatocopherol are fat soluble vitamins, it is not surprising that the low fat Round Goby is characterized by the lowest content of both fat soluble vitamins. A similar correlation between the lipid content and the levels of alpha-tocopherol in other fish species has been found by other authors (Ribarova et al., 2003; Özyurt et al., 2009).

The data about retinol and alpha-tocopherol content in edible fish tissues given by others were of the same order of magnitude as ours (Dias et al., 2003; Danish Food Composition Databank, 2007; USDA national nutrient data base, 2009; Whole Food Catalogue data base, 2009). Dias et al., (2003) measured $37 \mu \mathrm{g} .100 \mathrm{~g}^{-1}$ r.t. retinol and $740 \mu \mathrm{g} .100 \mathrm{~g}^{-1}$ r.t. alpha-tocopherol in the edible tissue of horse mackerel; in the Whole Food Catalogue data base (Whole Food Catalog data base, 2009) for the same fish were given $10 \mu \mathrm{g} .100 \mathrm{~g}^{-1}$ r.t. for retinol and $400 \mu \mathrm{g} .100 \mathrm{~g}^{-1}$ r.t. alpha-tocopherol. The USDA national nutrient data base published values of $33 \mu \mathrm{g} .100 \mathrm{~g}^{-1}$ r.t. for retinol and $1000 \mu \mathrm{g} .100 \mathrm{~g}^{-1}$ r.t. for alpha-tocopherol in raw Shad fish tissue (USDA national nutrient data base, 2009). In raw sprat fish tissue in the Danish food database was given a value of $150 \mu \mathrm{g} .100 \mathrm{~g}^{-1}$ r.t. for retinol, which is in a good agreement with our findings, whilst a much higher value for alphatocopherol (2500 $\mu$ g. $100 \mathrm{~g}^{-1}$ r.t.) compared to our

Table 2

Retinol and alpha-tocopherol content in edible fish tissue (mean \pm SD)*

\begin{tabular}{|c|c|c|}
\hline Fish species & $\begin{array}{c}\text { Retinol } \\
{\left[\mu \mathrm{g} .100 \mathrm{~g}^{-1} \text { r.t. }\right]}\end{array}$ & $\begin{array}{c}\text { alpha- } \\
\text { Tocopherol } \\
{\left[\mu \mathrm{g} .100 \mathrm{~g}^{-1} \text { r.t. }\right]}\end{array}$ \\
\hline Sprat & $142.3 \pm 4.4$ & $701.2 \pm 10.2$ \\
\hline Round goby & $8.9 \pm 0.1$ & $308.0 \pm 13.7$ \\
\hline $\begin{array}{l}\text { Black sea horse } \\
\text { mackerel }\end{array}$ & $32.7 \pm 0.3$ & $1112.7 \pm 39.2$ \\
\hline Shad & $22.3 \pm 0.2$ & $836.1 \pm 19.6$ \\
\hline
\end{tabular}

* All samples were analyzed in triplicate. 
results was indicated (Danish Food Composition Databank, 2007).

\subsection{Fatty acid composition}

A FA analysis enabled the classification and quantitative determination of individual FA as well as the sum of saturated fatty acids (SFA), monounsaturated fatty acids (MUFA), and polyunsaturated fatty acids (PUFA). The FA composition of the Black Sea fish species vary widely in their FA groups (Fig. 2). According to (Abbas et al., 2009) a relative pattern PUFA > MUFA > SFA is often found in the low-fat fish species (total lipids $<4 \mathrm{~g} .100 \mathrm{~g}^{-1}$ r.t.). Such significantly higher quantities in PUFA compared to MUFA ( $p<0.001$ ) and SFA $(p<0.001)$ were found for the round goby and sprat $(p<0.01)$ (Fig. 2). A deflection of this pattern was observed for the Black sea horse mackerel, a medium fatty fish (total lipids $\sim 4$ g. $100 \mathrm{~g}^{-1}$ r.t.) in which SFA content was significantly higher than MUFA $(p<0.001)$ and PUFA $(p<0.001)$. The shad, qualified as a fatty fish (total lipids $>10 \mathrm{~g} .100 \mathrm{~g}^{-1}$ r.t.), reveals significantly higher MUFA content compared PUFA $(p<0.001)$ (Fig. 2). The MUFAs are a dominant group in shad whereas in sprat and round goby they come closer to SFA content. The amounts of unsaturated FAs as MUFAs vary especially in wild fish. In our study only in round goby and Black Sea horse mackerel we found low MUFA levels.

The content of individual FA in fish lipids is strongly influenced by the FA composition of dietary lipids (Tocher, 2003). Many authors found out a great variation in FA content with predomination of palmitic (C16:0) and stearic (C18:0) SFA among the fish species (Tanakol et al., 1999; Tocher, 2003; Abbas et al., 2009). Our results also revealed that in all studied fish species the dominating SFAs were palmityc, stearic and myristic acid (Table 3). The highest levels of SFA were measured for palmityc acid, which is in agreement with the results of Tanakol et al. finding highest levels of palmitic and stearic acid in several Black Sea fish species. Similar results were obtained by other authors for seawater fish species (FAO/WHO, 1994; Tanakol et al., 1999; Özogul and Özogul, 2007).

Among MUFAs in all studied fish species (Alosa pontica, Neogobius rattan, Sprattus sprattus, Trahurus medditeraneus ponticus) the highest levels were found for palmitoleic acid followed by oleic and erucic acid. It was interesting to mention that in the sprat were found the highest levels of erucic and lowest - in the Black sea horse mackerel. It may be supposed that the low MUFA levels in the round goby and horse mackerel are related to the high concentrations of palmitoleic, oleic and erucic acid in these fish species (Table 3).

Many studies reported that the oleic acid is the main MUFAin seawater fish species (Tanakol et al., 1999; Saglik and Imre, 2001; Özogul and Özogul, 2007; Abbas et al., 2009). According to Tanakol et al., (1999) and Saglik and Imre (2001), the highest

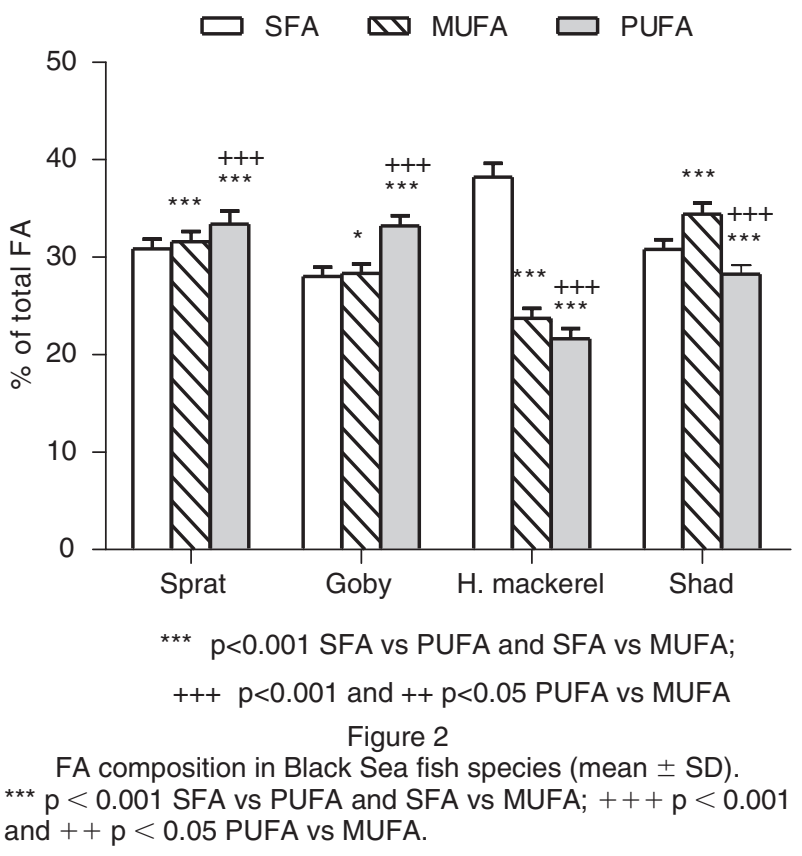

levels of oleic acid (up to $13.00 \%$ ) on a face of low levels of palmitoleic acid were measured in the Black Sea turbot fish (Özogul and Özogul, 2007). On the contrary, in some Mediterranean and Aegean fish species such as mullet (Mugul cephalus) and sardine (Sardinella aurita), were found large amounts of palmitoleic acid and low levels of oleic acids (Özogul and Özogul, 2007). In the fish tissues, the oleic acid is of exogenous origin and usually reflects the type of fish diet. Among European semi-enclosed and coastal seas, the Black Sea is the most isolated from the deep oceans. The biological consequence of the excess nutrient run off from incoming rivers is the most intense eutrophication in the world, thus transforming the Black Sea ecosystem (Zaitsev, 1992). It is supposed that because of the decline in populations of zooplankton and the increase of phytoplankton mass, as a response to the eutrophication in the Black Sea, the fish species in the Black sea region revealed low levels of MUFAs such as C20:1 and high levels of C22:1 and n3 PUFAs (Zaitsev, 1992; Tanakol et al., 1999; Özogul and Özogul, 2007). Our results are in agreement with this hypothesis revealing low C20:1 acid level in the round goby $(1.50 \%)$ and shad $(2.45 \%)$ and high C22:1 levels in the round goby $(2.00 \%)$ and in the sprat $(4.00 \%)$.

Four major PUFAs were identified as dominant: C22:6 n3, cis-linoleic (LA, C18:2 n6), C20:5 n3 and arachidonic acid (ARA, C20:4 n6) (Table 3). Significant amounts of the biologically important PUFAs such as C22:6 n3, C18:2 n6, C20:5 n3 and C20:4 n6 were found in all studied fish species. Among them, the predominant FA was found to be C22:6 n3. The highest levels of C22:6 n3 were measured in the high-fat shad $(74.50 \%$ of total PUFAs) and the lowest values in the low-fat round goby (48.80\% of total PUFAs), (Table 3). A possible explanation is that fatty fishes are the main sources of C18:3 n3 effectively converted to C22:6 n3 (Tocher, 2003). Other authors reporting high 
Table 3

Fatty Acid composition in Black Sea fish species (mean \pm SD)

\begin{tabular}{|c|c|c|c|c|}
\hline FA, \% & Sprat & Round goby & Horse mackerel & Shad \\
\hline \multicolumn{5}{|c|}{ Saturated fatty acid group (SFA) } \\
\hline C 12:0 & $0.20 \pm 0.02$ & $0.02 \pm 0.01$ & $0.12 \pm 0.02$ & $0.05 \pm 0.01$ \\
\hline C 14:0 & $3.50 \pm 0.12$ & $2.50 \pm 0.20$ & $1.05 \pm 0.10$ & $2.68 \pm 0.80$ \\
\hline C 16:0 & $23.80 \pm 1.23$ & $24.0 \pm 0.98$ & $32.12 \pm 1.43$ & $26.02 \pm 1.01$ \\
\hline C 17:0 & $0.36 \pm 0.08$ & $0.14 \pm 0.07$ & $0.24 \pm 0.08$ & $0.24 \pm 0.03$ \\
\hline C 18:0 & $2.70 \pm 0.40$ & $1.08 \pm 0.20$ & $4.17 \pm 0.40$ & $1.54 \pm 0.27$ \\
\hline C 20:0 & $0.07 \pm 0.01$ & $0.07 \pm 0.02$ & $0.14 \pm 0.02$ & $0.10 \pm 0.02$ \\
\hline C 22:0 & $0.09 \pm 0.01$ & $0.05 \pm 0.03$ & $0.14 \pm 0.03$ & $0.06 \pm 0.015$ \\
\hline C 24:0 & $0.09 \pm 0.01$ & $0.05 \pm 0.01$ & $0.15 \pm 0.02$ & $0.05 \pm 0.031$ \\
\hline \multicolumn{5}{|c|}{ Monounsaturated fatty acid group (MUFA) } \\
\hline C $14: 1$ & $0.03 \pm 0.01$ & $0.02 \pm 0.01$ & $0.05 \pm 0.01$ & $0.03 \pm 0.01$ \\
\hline C $16: 1$ & $12.30 \pm 1.05$ & $15.00 \pm 0.89$ & $11.8 \pm 1.05$ & $16.82 \pm 1.10$ \\
\hline C $17: 1$ & $0.35 \pm 0.02$ & $0.20 \pm 0.03$ & $0.12 \pm 0.03$ & $0.29 \pm 0.01$ \\
\hline cis C 18:1 n9 & $9.50 \pm 0.60$ & $8.13 \pm 0.60$ & $7.55 \pm 0.10$ & $9.35 \pm 0.60$ \\
\hline trans C 18:1 n9 & $0.40 \pm 0.01$ & $0.80 \pm 0.05$ & $0.55 \pm 0.06$ & $1.03 \pm 0.60$ \\
\hline C 20:1 & $1.93 \pm 0.40$ & $1.50 \pm 0.11$ & $0.51 \pm 0.04$ & $2.45 \pm 0.30$ \\
\hline C 22:1 n9 & $4.01 \pm 0.90$ & $2.00 \pm 0.15$ & $0.13 \pm 0.04$ & $3.10 \pm 0.70$ \\
\hline C 24:1 & $3.10 \pm 0.40$ & $0.70 \pm 0.10$ & $2.31 \pm 0.40$ & $1.49 \pm 0.19$ \\
\hline \multicolumn{5}{|c|}{ Polyunsaturated fatty acid group (PUFA) } \\
\hline C $18: 3 \mathrm{n} 6$ & $0.13 \pm 0.04$ & $0.03 \pm 0.02$ & $0.14 \pm 0.04$ & $0.04 \pm 0.01$ \\
\hline cis $\mathrm{C} 18: 2 \mathrm{n} 6$ & $5.68 \pm 1.30$ & $11.29 \pm 0.97$ & $1.30 \pm 0.20$ & $5.21 \pm 0.65$ \\
\hline trans C $18: 2 \mathrm{n} 6$ & $0.40 \pm 0.02$ & 0.00 & $0.15 \pm 0.01$ & $0.22 \pm 0.01$ \\
\hline C $18: 3$ n3 & $1.40 \pm 0.50$ & $0.54 \pm 0.04$ & $0.40 \pm 0.05$ & $0.41 \pm 0.07$ \\
\hline C $20: 5$ n3 & $0.23 \pm 0.02$ & $1.89 \pm 0.15$ & $0.38 \pm 0.02$ & $0.13 \pm 0.01$ \\
\hline C 20:4 n6 & $4.86 \pm 0.80$ & $3.12 \pm 0.30$ & $0.71 \pm 0.08$ & $0.45 \pm 0.01$ \\
\hline C 20:2 & $0.31 \pm 0.01$ & $0.08 \pm 0.01$ & $0.31 \pm 0.02$ & $0.15 \pm 0.01$ \\
\hline C 20:3 n3 & $0.27 \pm 0.05$ & $0.06 \pm 0.01$ & $0.27 \pm 0.03$ & $0.07 \pm 0.01$ \\
\hline C 22:6 n3 & $17.01 \pm 0.99$ & $16.03 \pm 1.02$ & $18.31 \pm 1.30$ & $21.04 \pm 0.95$ \\
\hline C 22:2 & $1.27 \pm 0.80$ & $0.06 \pm 0.01$ & $0.17 \pm 0.08$ & $0.06 \pm 0.02$ \\
\hline
\end{tabular}

amounts of $\mathrm{C} 20: 5 \mathrm{n} 3$ and $\mathrm{C} 22: 6 \mathrm{n} 3$ in seawater fish species (Bluefish, European anchovy, etc) confirm also this finding, (Saglik and Imre, 2001). On the contrary, our results revealed low C20:5 n3 levels in the sprat, shad, and horse mackerel and high C20:5 n3 levels in the round goby. For all studied fish species the C20:4 n6 levels were lower than those of C22:6 n3 and C18:2 n6 (Table 3). The pelagic and demersal fish species (such as ours) feed predominantly on the pelagic phytoplankton food web, which contains low levels of C20:4 n6 (Abbas et al., 2009). This marine food chain from phytoplankton via zooplankton to fish is one of the main reasons for accumulation of a significant amounts of C20:5 n3 and C22:6 n3.

All studied fish species are characterized with relatively high levels of $n 3$ FA and low levels of n6 FA
(Table 4). The total content of n3 FAs was significantly higher $(p<0.001)$ than the total content of n6 FAs in each of the analyzed fish samples, with highest levels found in the shad (Table 4). Dietary intake of n3 FA may prevent the development of many chronic diseases including coronary heart disease, diabetes, arthritis, cancer, osteoporosis, and mental disorders (Culyer, 1994; Simopoulos and Cleland, 2003). Recently, an increasing general view is that for a healthy diet is essential to increase the n3 and decrease the n6 FA intake in order to have a balanced intake of $n 6$ and n3 FA (Simopoulos and Cleland, 2003; Abbas et al., 2009).

The n6/n3 FA ratio has been suggested to be an useful indicator for comparing the relative nutritional value of a given fish. According to the UK Department of Health, a ratio within $0.20-1.50$ would constitute a 
Table 4

PUFA/SFA and $n 6 / n 3$ ratios, total sum of $n 3$ and $n 6$ FA content

\begin{tabular}{lcccc}
\hline \multicolumn{1}{c}{ Fish species } & Sprat & Round goby & $\begin{array}{c}\text { Black sea horse } \\
\text { mackerel }\end{array}$ & Shad \\
\hline Total sum n3 FA [\% of total FA] & $19.90 \pm 1.8^{\star \star \star}$ & $17.51 \pm 1.5^{\star \star \star}$ & $19.36 \pm 1.6^{\star * \star}$ & $22.64 \pm 2.1^{\star \star \star}$ \\
Total sum n6 FA [\% of total FA] & $11.90 \pm 1.1^{\star \star *}$ & $4.65 \pm 0.8^{\star \star *}$ & $1.80 \pm 0.5^{\star * *}$ & $5.41 \pm 0.9^{\star \star *}$ \\
n6/n3 FA & 0.59 & 0.26 & 0.10 & 0.23 \\
PUFA/SFA & 1.08 & 1.19 & 0.56 & 0.94 \\
\hline
\end{tabular}

*** $p<0.001$, n3 vs n6 FA.

healthy human diet and values higher than 1.50 would be harmful and may promote cardiovascular diseases (Culyer, 1994). For three of the studied Black Sea fish species - sprat, round goby and shad, the n6/n3 FA ratio was within the recommended range (Table 4). Values for PUFA/SFA ratio greater than 0.45 are recommended (Culyer, 1994). Our results are in agreement with this requirement showing higher PUFA/SFA ratios for all studied fish species (Table 4). The highest PUFA/SFA ratio was observed in the round goby, followed by sprat and shad, whereas the lowest value was found for Black sea horse mackerel. The most balanced PUFA/SFA ratio was obtained for the sprat and shad.

\section{CONCLUSIONS}

The present study provides information about the total lipids, retinol and alpha-tocopherol content, and FA composition of four traditionally consumed Black Sea fish species in Bulgaria. Regarding to the high levels of the analyzed fat soluble vitamins, FA composition, n3/n6 FA and PUFA/SFA ratios we may conclude that these four Black Sea fish species have a good nutritional quality.

\section{ACKNOWLEDGMENTS}

This study was financed by the National Science Fund, Ministry of Education and Science of Bulgaria (Project DVU 440/2008).

\section{REFERENCES}

Abbas KA, Mohamed A, Jamilah B. 2009. Fatty acid in fish and beef and their nutritional values: A review. $J$. Food Agric. Environ. 7, 37-42.

Anderson J, Young L. 2008. Fat-Soluble Vitamins. Food and Nutrition series, Colorado State University. 9, 315.

BDS EN ISO 5509:2000. Animal and vegetable fats and oils-Preparation of methyl esters of fatty acids.

BDS EN ISO 5508:2000. Animal and vegetable fats and oils-Analysis by gas chromatography of methyl esters of fatty acids.

Bligh E \& Dyer W.J. 1959. A rapid method of total lipid extraction and purification. Canadian J. Biochem. Physiol. 37, 913-917.

Culyer A. 1994. Supporting research and development in the NHS: a report to the Minister of Health. London: HMSO, ISBN: 0113218311.
Danish Food Composition Databank, Department of Nutrition, National Food Institute 2007, http://www. foodcomp.dk/v7/fcdb grpsearchres.asp?Main Grp $=08$

Dias MG, Sanchez MV, Bartolo H, Oliveira L. 2003. Vitamin content of fish and fish products consumed in Portugal. Electron. J. Environ. Agric. Food Chem. 4, 510-513.

FAO/WHO 1994. Scientific and ethical challenges in agriculture to meet human needs, http://www.fao.org/ docrep/003/X8576M/x8576m05.htm

Huynh MD, Kitts DD. 2009. Evaluating nutritional quality of pacific fish species from fatty acid signatures. Food Chem. 114, 912-918.

Kuhnlein HV, Barthet V, Farren A, Falahi E, Leggee D, Receveur O, Berti P. 2006. Vitamins A, D, and E in Canadian Arctic traditional food and adult diets. J. Food Compos. Anal. 19, 495-506.

Lopez-Cervantes J, Sanchez-Machado DI, Rios-Vazquez N.J. 2006. High-performance liquid chromatography method for the simultaneous quantification of retinol, alpha-tocopherol, and cholesterol in shrimp waste hydrolysate. J. Chromatogr. A 1105, 135-139.

National Strategic Plan for Fisheries and Aquaculture 2007-2013, Ministry of Agriculture and Forestry, Sofia, Bulgaria.

Ozyurt G, Polat A, Loker G.B. 2009. Vitamin and mineral content of pike perch (Sander lucioperca), common carp (Cyprinuscarpio), and European catfish (Silurusglanis). Turkish J. Vet. Anim. Sci. 33, 351-356

Özogul Y, Özogul F. 2007. Fatty acid profiles and fat content of commercially important seawater and freshwater fish species of Turkey: A comparative study. Food Chem. 100, 1634-1638.

Ribarova F, Zanev R, Shishkov S, Rizov N. 2003. $\alpha$-tocopherol, fatty acids and their correlations in Bulgarian foodstuffs. J. Food Compos. Anal. 16, 659-667.

Saglik S, Imre S. 2001. Omega 3-fatty acids in some fish species from. Turkey. J. Food Sci. 66, 210-212.

Simopoulos A, Cleland L. 2003. Omega-6/Omega-3 Essential Fatty Acid Ratio: The Scientific Evidence. World Review Nutr. Diet. 92,57-73.

Tanakol R, Yazici Z, Sener E, Sencer E. 1999. Fatty Acid Composition of 19 Species of Fish from the Black Sea and Marmara Sea. Lipids 34, 291-294.

Tocher D. 2003. Metabolism and Functions of Lipids and Fatty Acids in Teleost Fish. Reviews in Fisheries Sc. 11, 107-184.

USDA national nutrient database 2009. http://fn.cfs.purdue. edu/fish4health/HealthBenefits/shad(American).pdf

Whole Food Catalog data base 2009. http://wholefoodcatalog. info/food/horse mackerel(raw)/nutrients/

Zaitsev Y. 1992. Recent changes in the trophic structure of the Black Sea. Fish. Oceanogr. 2, 180-189.

Recibido: 21/6/11 Aceptado: 11/10/11 